\title{
Effect of Intraduodenal Bile and Taurodeoxycholate on Exocrine Pancreatic Secretion and on Plasma Levels of Vasoactive Intestinal Polypeptide and Somatostatin in Man
}

\author{
Rudolf L. Riepl, Fritz Fiedler, Johannes Teufel, and Peter Lehnert \\ Medical Clinic, Klinikum Innenstadt, University of Munich, Munich, Germany
}

Summary: Intraduodenal (i.d.) application of bile or Nataurodeoxycholate (TDC) dose dependently enhances basal exocrine pancreatic secretion. The hydrokinetic effect is mediated at least in part by secretin. This study should show, whether vasoactive intestinal polypeptide (VIP), a partial agonist of secretin, may also be involved in the mediation of the hydrokinetic effect. Furthermore, plasma concentrations of somatostatin-like immunoreactivity (SLI) were measured in order to check whether this counterregulating hormone is also released by bile and TDC. Twenty investigations were carried out on 10 fasting healthy volunteers provided with a double-lumen Dreiling tube. Bile and TDC were intraduodenally applied in doses of $2-6 \mathrm{~g}$ and $200-600 \mathrm{mg}$, respectively, at $65-\mathrm{min}$ intervals. Plasma samples were withdrawn at defined intervals for radioimmunological determination of VIP and SLI. Duodenal juice was collected in 10-min fractions and analyzed for volume, pH, bicarbonate, lipase, trypsin, and amylase. I.d. application of bile or TDC dose dependently stimulated hydrokinetic and ecbolic pancreatic secretion. Bile exerted a slightly stronger effect than TDC. Pancreatic response was simultaneously accompanied by a significant increase of plasma VIP and SLI concentrations. The effect of bile on integrated plasma VIP and SLI concentrations seems to be dose dependent; the effect of TDC on integrated SLI, too. For the increase of integrated plasma VIP concentrations after TDC no doseresponse relation could be established. We conclude that VIP may be a further mediator of bile-induced volume and bicarbonate secretion. The release of plasma SLI indicates that inhibitory mechanisms concomitantly are triggered by i.d. bile and TDC, as already shown during digestion for the intestinal phase of pancreatic secretion. Key Words: Bile-Duodenum-Pancreatic secretionSomatostatin-Taurodeoxycholate-Vasoactive intestinal polypeptide.
Intraduodenal (i.d.) application of bile or $\mathrm{Na}$ taurodeoxycholate (TDC) dose dependently enhances basal (1) and secretin-stimulated (2) hydrokinetic and ecbolic pancreatic secretion in man. The pancreatic response to i.d. bile $(1,3,4)$ or bile salts $(1,5,6)$ is accompanied by a release of secretin, the most important hormonal mediator of pancreatic volume and bicarbonate secretion (7-9).

Vasoactive intestinal polypeptide (VIP) acts as a

Manuscript received September 10, 1992; revised manuscript accepted January 29, 1993.

Address correspondence and reprint requests to $\mathrm{Dr}$. med. R. L. Riepl, Medizinische Klinik, Klinikum Innenstadt der Universität München, Ziemssenstr. 1, D-80336 München, Germany.

A preliminary report of this work was presented at the 25th annual meeting of the European Society for Clinical Investigation, Pisa, Italy, 1991, and published as abstract (50). weak hydrokinetic stimulus (10) in man. Burhol et al. (11) were able to show in man, that i.d. application of bile induces an increase of pancreatic hydrokinetic function and a release of VIP as well. In this investigation, however, only a single, high dose (6 g) of bile was applied. Moreover, Chayvialle et al. (12) were not able to demonstrate a release of VIP in both portal and peripheral plasma after i.d. bile ( 3 g) in dogs. Therefore, one purpose of the present study was to investigate in man, whether VIP is dose dependently released by physiological loads of bile or TDC, a very effective bile salt with regard to pancreatic secretion (2).

The intestinal phase of pancreatic secretion represents a net sum resulting from the responses to stimulatory and inhibitory mechanisms, as well (13). As we previously showed in man (1), i.d. ap- 
plication of bile or TDC dose dependently increases the plasma levels of pancreatic polypeptide (PP), an inhibitor of pancreatic secretion (14). In dogs, Chayvialle et al. (12) observed a bile-induced release of somatostatin, a potent inhibitor of exocrine pancreatic function $(15,16)$. On the contrary, Burhol et al. (17) did not find an augmentation of plasma somatostatin by bile in man. Therefore, another aim of our study was to reexamine the influence of bile and TDC on the release of somatostatin-like immunoreactivity (SLI) in man.

\section{METHODS}

\section{Experimental procedure}

Twenty experiments were carried out on 10 fasting young healthy subjects. Full written consent was obtained from each subject, and the research protocol was approved by the Ethics Committee at the Medical Faculty.

A double-lumen Dreiling tube was advanced to the ligament of Treitz under fluoroscopic control enabling continuous and separate aspiration of gastric and duodenal juice. Details have been described elsewhere $(1,2)$. On one day, standardized dried cattle bile (kindly supplied by Kali-Chemie, Hannover, FRG), dissolved in $20 \mathrm{ml} \mathrm{H}_{2} \mathrm{O}$, was applied i.d. in doses of 2 (twice), 4 , and $6 \mathrm{~g}(310,639$, and $937 \mathrm{mosmol} / \mathrm{L} ; \mathrm{pH} 7.45,7.18$, and 7.04, respectively) at 65-min intervals. On another day, chromatographically pure TDC (Calbiochem-Behring, FRG), again dissolved in $20 \mathrm{ml} \mathrm{H}_{2} \mathrm{O}$, was used in doses of 200 (twice), 400, and $600 \mathrm{mg}(19.0,38.5$, and $57.5 \mathrm{mmol} / \mathrm{L}$ corresponding to $33.0,50.0$, and

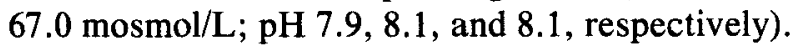
The first stimulus in each series-2 $\mathrm{g}$ bile or $200 \mathrm{mg}$ TDC, respectively-was given in order to "wash out" preformed zymogens from the pancreatic ducts.

The bile preparation used in this study contained $10 \%$ TDC based on weight. In order to compare the effects of total bile and TDC, respectively, doses of TDC were administered corresponding to the amounts applied with bile (e.g., $2 \mathrm{~g}$ bile contain 200 mg TDC). Duodenal juice was collected in 10-min fractions and analyzed for volume, $\mathrm{pH}$, bicarbonate, lipase, trypsin, and amylase. The $\mathrm{pH}$ values of the duodenal aspirate were within the neutral range after all i.d. stimuli. The determination of pancreatic enzymes and bicarbonate was performed according to the recommendation of the Multi-CentreStudy of the European Pancreatic Club (18). Blood samples for radioimmunological determination of
VIP and SLI were drawn from a peripheral vein in ice-chilled $10-\mathrm{ml}$ syringes (containing $37.1 \mu \mathrm{mol} \mathrm{K} \mathrm{K}_{2}$ ethylenediaminetetraacetic acid (EDTA) and 5000 KIU aprotinin) before, at, and 5, 10, 15, 25, 45, and $65 \mathrm{~min}$ after i.d. application of bile or TDC. The samples were immediately centrifuged at $4^{\circ} \mathrm{C}$, the plasma stored at $-20^{\circ} \mathrm{C}$.

\section{Radioimmunoassay procedures}

Before the assays plasma samples were extracted with acetone. The supernatant was decanted and dried in a vacuum centrifuge (SpeedVac). The dried product was reconstructed to the original volume with assay buffer containing $0.1 \mathrm{M}$ sodium citrate buffer ( $\mathrm{pH} 6.5), 0.07 \mathrm{mmol} / \mathrm{L}$ bovine serum albu$\mathrm{min}, 3.08 \mathrm{mmol} / \mathrm{L} \mathrm{NaN}_{3}, 500 \mathrm{KIU} / \mathrm{ml}$ aprotinin, and $50 \mu \mathrm{l} / \mathrm{L}$ polyoxyethylenesorbitan monolaurate (Tween 20).

\section{$V I P$}

Our VIP-antiserum (VI2X, $\mathrm{K}_{\text {eff }}=1.0 \times 10^{11}$ $\mathrm{L} / \mathrm{mol}$ ) showed no cross-reactivity with $\mathrm{VIP}_{1-12}$, other peptides of the secretin-glucagon family, and somatostatin-14. [ $\left.{ }^{125} \mathrm{I}\right]$ VIP (81.4 MBq/nmol; NEN, Dreieich, FRG) was used as tracer. The standard (400 $\mu l$, synthetic VIP; Sigma, Munich, FRG) and the sample $(400 \mu \mathrm{l})$ were incubated with $100 \mu \mathrm{l}$ of a VIP antiserum/anti-rabbit $\gamma$-globulin antiserum precipitate (dilution of VIP antiserum 1:54,000), and $100 \mu \mathrm{l}$ of the tracer $(\approx 1 \mathrm{fmol})$ in assay buffer. After $96 \mathrm{~h}$ in incubation bound and free label were separated by centrifugation at $4^{\circ} \mathrm{C}$, the supernatant removed by suction, and the precipitate counted in an automatic $\gamma$-counter as described previously (1). The detection limit of the assay was $1 \mathrm{pmol} / \mathrm{L}$ with 95\% confidence limit. Recovery of known amounts of $\operatorname{VIP}(3.9,7.1$, and $35.4 \mathrm{pmol} / \mathrm{L})$ in human plasma was $50 \pm 3 \%(\overline{\mathrm{x}} \pm \mathrm{SD})$ at each concentration. The coefficient of variation for the within-assay precision was $13.3,13.4$, and $9.9 \%$ at 3.0, 15.7, and 51.3 $\mathrm{pmol} / \mathrm{L}$, respectively, and for the between-assay precision 15.3 and $13.9 \%$ at 12.4 and $27.4 \mathrm{pmol} / \mathrm{L}$, respectively.

\section{Somatostatin}

Our antiserum against somatostatin-14 (SO4VIII, $\mathrm{K}_{\text {eff }} 1.1 \times 10^{11} \mathrm{~L} / \mathrm{mol}$ ) showed a cross-reactivity of $80 \%$ with somatostatin-28 and none with gastrin17(I), gastrin-34(I), sulfated cholecystokinin (CCK)-8 and CCK-33, peptides of the secretinglucagon family, PP, peptide YY (PYY), and neuropeptide $\mathrm{Y}$ (NPY). [ $\left.{ }^{125} \mathrm{I}\right]-\mathrm{Tyr}_{1}$-somatostatin-14 (81.4 MBq/nmol; NEN, Dreieich, FRG) was used 
as tracer. The standard $(300 \mu l$, synthetic somatostatin-14; Sigma, Munich, FRG) and the sample $(300 \mu l)$ were incubated with $100 \mu l$ of a somatostatin antiserum/anti-rabbit $\gamma$-globulin antiserum precipitate (dilution of somatostatin antiserum $1: 280,000)$, and $100 \mu \mathrm{l}$ of the tracer $(\approx 1 \mathrm{fmol})$ in assay buffer. Incubation and separation procedures were identical to those of VIP. The detection limit of the assay was $1 \mathrm{pmol} / \mathrm{L}$ with $95 \%$ confidence limit. Recovery of synthetic somatostatin-14 (2.6, 11.5 , and $56.9 \mathrm{pmol} / \mathrm{L}$ ) in human plasma was $57 \pm$ $4 \%(\overline{\mathrm{x}} \pm \mathrm{SD})$ at each concentration. The intra-assay coefficient of variation was 14.8 and $7.8 \%$ at 2.7 and $15.4 \mathrm{pmol} / \mathrm{L}$, respectively; the interassay coefficient of variation was 11.1 and $7 \%$ at 12.6 and $64.1 \mathrm{pmol} /$ L, respectively.

Gel chromatography studies showed that VIP immunoreactivity in extracted plasma, synthetic VIP, and $\left[{ }^{125} \mathrm{I}\right]$-VIP eluted at identical positions. After i.d. application of $6 \mathrm{~g}$ bile, somatostatin-like immunoreactivity in extracted plasma is eluted at two peaks corresponding to somatostatin-14 and somatostatin-28 (40 and $60 \%$ of total SLI, respectively). Because of this heterogeneity the term somatostatin-like immunoreactivity is used.

\section{Statistical methods}

All data were evaluated by the Friedman twoway analysis of variance; $p \leqslant 0.05$ was considered statistically significant. The value before the second application of $2 \mathrm{~g}$ bile or $200 \mathrm{mg}$ TDC, respectively, was used as "basal." It proved to be statistically not different from the other prestimulatory values. In all figures values are presented as $\bar{x} \pm$ SEM. Integrated VIP and SLI values were calculated as the areas under the concentration curves for $10 \mathrm{~min}$ after application of each i.d. stimulus.

\section{RESULTS}

Plasma VIP concentrations significantly increased after all doses of bile and after 200 and 600 mg of TDC (Figs. 1 and 2, top). Integrated plasma VIP was significantly enhanced by 4 and $6 \mathrm{~g}$ of bile and by $200 \mathrm{mg}$ of TDC (Fig. 3, top). Integrated VIP was significantly higher after $6 \mathrm{~g}$ of bile as compared with 2 and $4 \mathrm{~g}$.

Plasma SLI concentrations were significantly raised by all doses of bile and TDC (Figs. 1 and 2, bottom). Integrated SLI significantly and dose dependently rose after all doses of bile and after 200 and $400 \mathrm{mg}$ of TDC; after $600 \mathrm{mg}$ of TDC no further

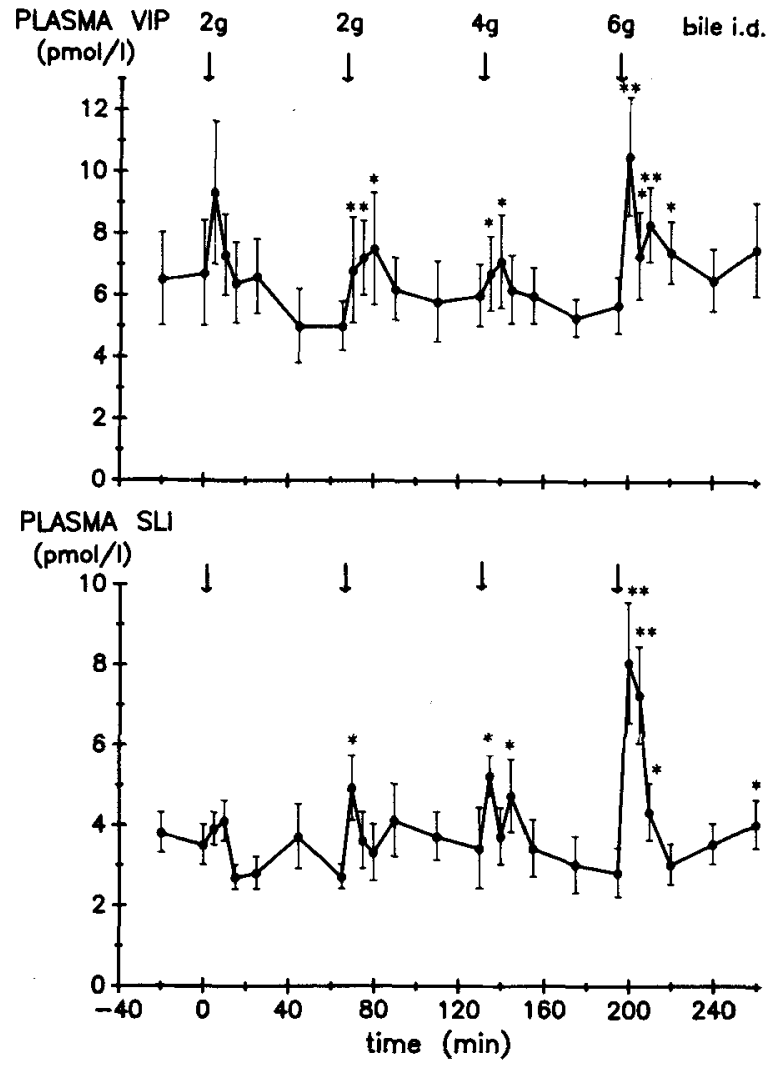

FIG. 1. Effect of 2, 2, 4, and $6 \mathrm{~g}$ of bile in the duodenum on the kinetics of plasma VIP (top) and SLI (bottom) concentrations ( $n$ $=10$ ). A single asterisk indicates $p \leqslant 0.05$ and two asterisks $p \leqslant$ 0.01 compared with the basal value preceding the second i.d. stimulus (also in Figs. 2-5).

increase of SLI was observed as compared with 400 mg (Fig. 3, bottom).

Parallel to the peptide release, volume, bicarbonate, lipase, trypsin, and amylase secretion significantly increased after 4 and $6 \mathrm{~g}$ bile and after all doses of TDC (Fig. 4; Table 1). After $2 \mathrm{~g}$ bile the increase was significant only for lipase. Volume secretion and bicarbonate output showed a dosedependent augmentation after both i.d. stimuli, whereas enzyme output did not further increase after the highest dose of bile and TDC, respectively (Fig. 5; Table 1). Comparing the hydrokinetic and ecbolic effect of bile and TDC, a tendency to higher values was found after bile, reaching significance, however, only for bicarbonate after the respective highest dose (Fig. 4; Table 1).

\section{DISCUSSION}

The present study shows, that i.d. application of bile or TDC enhances plasma VIP and SLI levels 


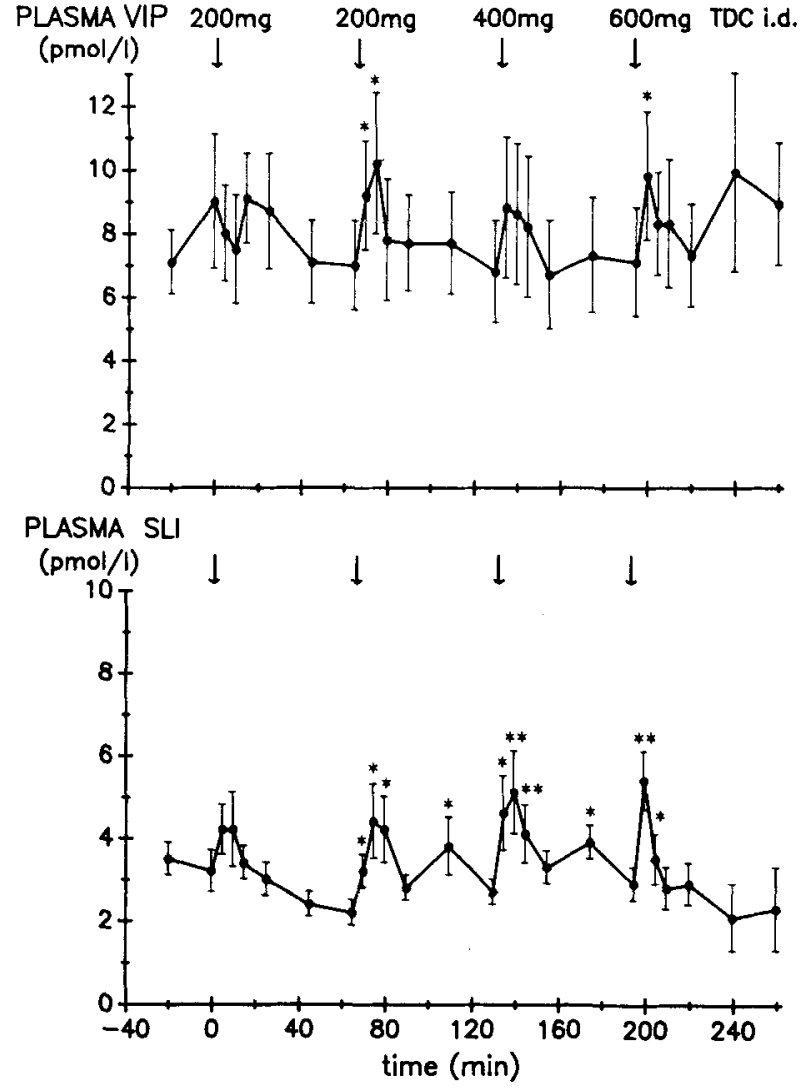

FIG. 2. Effect of $200,200,400$, and $600 \mathrm{mg}$ of TDC in the duodenum on the kinetics of plasma VIP (top) and SLI (bottom) concentrations $(n=10)$.

simultaneously with an increase of hydrokinetic and ecbolic pancreatic secretion.

The results are in accordance with our previous findings $(1,2)$ that physiologic amounts of i.d. bile and TDC dose dependently stimulate volume, bicarbonate, lipase, trypsin, and amylase secretion in man (Figs. 4, 5; Table 1). The applied bile solution contained $10 \%$ TDC. In order to compare the effects of total bile and TDC, respectively, corresponding amounts of this bile salt were used. On this basis, TDC showed a slightly lower pancreatic response as compared with bile, reaching significance, however, only for bicarbonate after $600 \mathrm{mg}$ TDC vs. $6 \mathrm{~g}$ bile. This observation is in agreement with another study showing that the effect of TDC can further be enhanced by combination with other bile salts (19).

The stimulatory effect of bile salts does not depend on their action as detergents (20) or their acidity (21). Moreover, the $\mathrm{pH}$ of the solutions applied was kept neutral or slightly alkaline to exclude stimulation of pancreatic secretion by acid equivalents.
Furthermore, the osmolality of the applied solutions cannot account for the stimulatory effect of bile and TDC, because i.d. infusion of a $20 \%$ solution of mannitol $(1,097 \mathrm{mosmol} / \mathrm{kg})$ in man caused only a slight enhancement of volume secretion but exerted no effect on bicarbonate and enzyme output $(22)$. Others $(23,24)$ found no or even an inhibitory effect on pancreatic secretion by raising the osmolality of i.d. applied solutions in dogs.

The method of repeated stimulus application was chosen, because intraindividual responses in experiments on different days vary considerably. Intervals of $65 \mathrm{~min}$ between stimulus applications were established to allow pancreatic secretion and peptide concentrations to return to prestimulatory values.

Previously, Burhol et al. (11) were able to demonstrate an increase of plasma VIP concentrations after i.d. application of a single dose of $6 \mathrm{~g}$ bile in man. Our data confirm this observation and show that 2 and $4 \mathrm{~g}$ i.d. bile also significantly enhance plasma VIP concentrations (Fig. 1). Furthermore, integrated plasma VIP was significantly higher after $6 \mathrm{~g}$ bile as compared with 2 and $4 \mathrm{~g}$ bile, probably
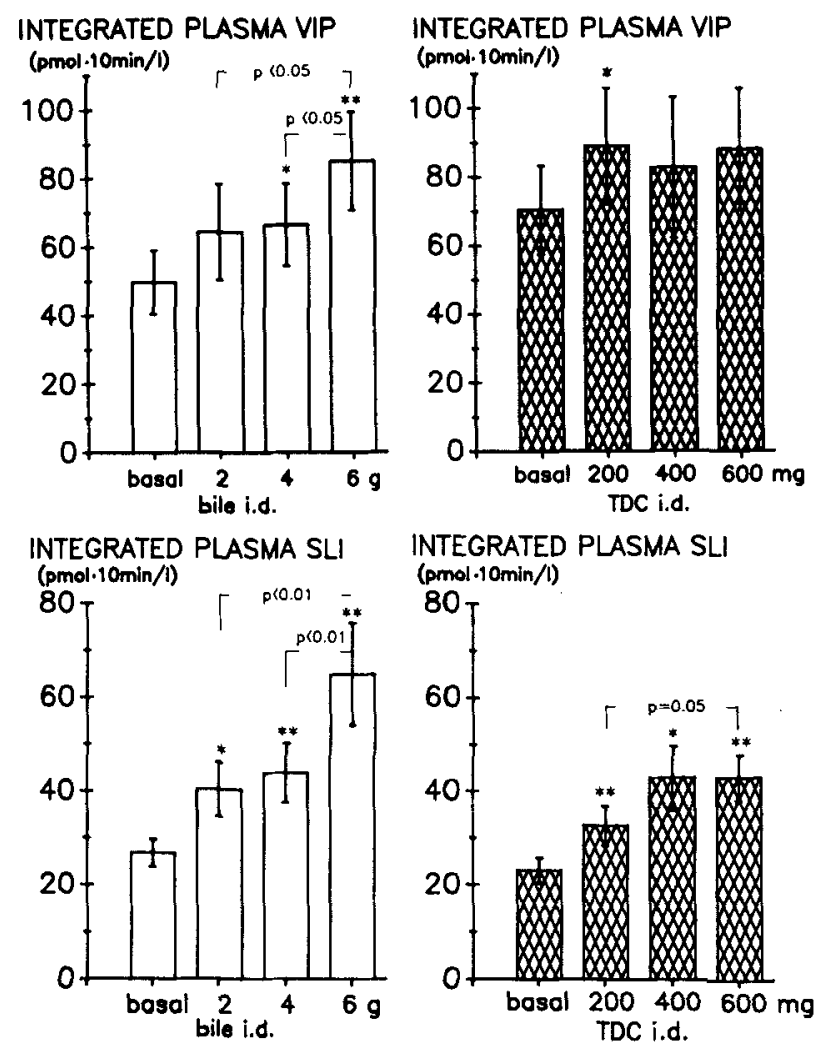

FIG. 3. Dose-response plot of i.d. bile (left) and TDC (right) on integrated plasma VIP (top) and SLI (bottom) $(n=10)$. 

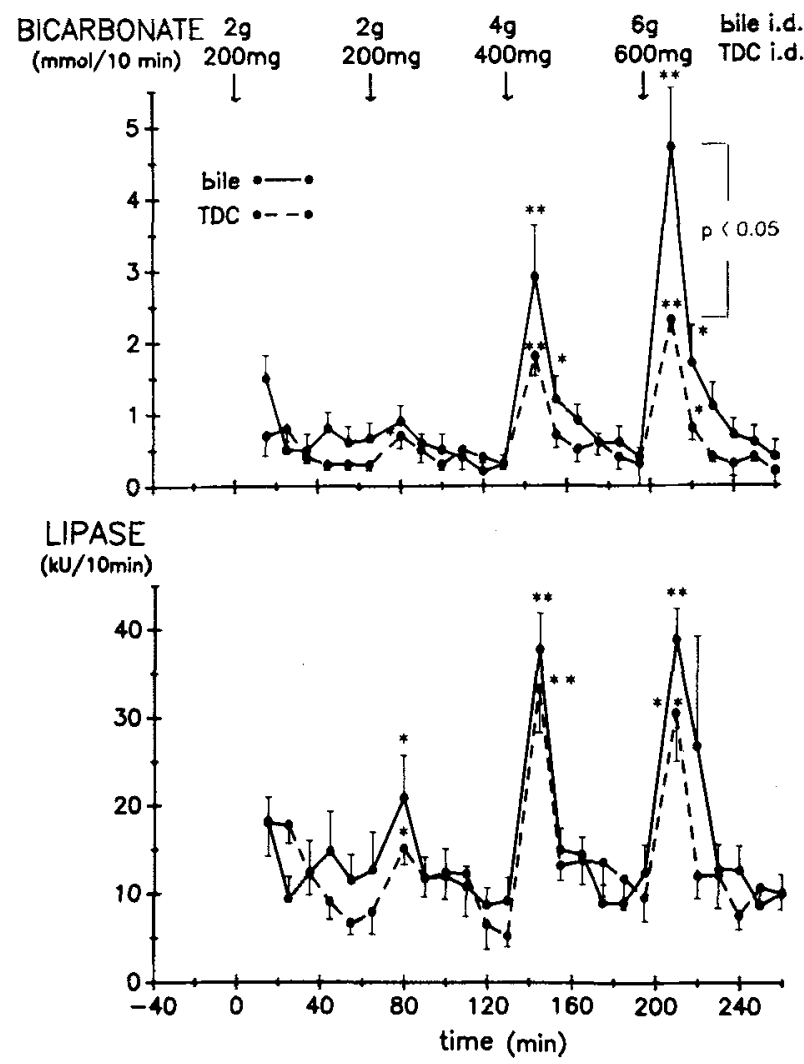

FIG. 4. Effect of 2, 2, 4, and $6 \mathrm{~g}$ of bile $(-)$ and of 200,200 , 400 , and $600 \mathrm{mg}$ of TDC (•-.-•) on pancreatic bicarbonate (top) and lipase (bottom) secretion rate $(n=10)$. Lipase is representative for all enzymes measured.

indicating a dose-response relation (Fig. 3). An enhancement of VIP levels secondary to an acid release into the duodenum (25) was prevented by continuous aspiration of gastric juice and documented by the neutral $\mathrm{pH}$ of the duodenal aspirate. Furthermore, it is unlikely that the osmolality of the bile solutions is responsible for the VIP release, since Schaffalitzky de Muckadell et al. (25) found no in-

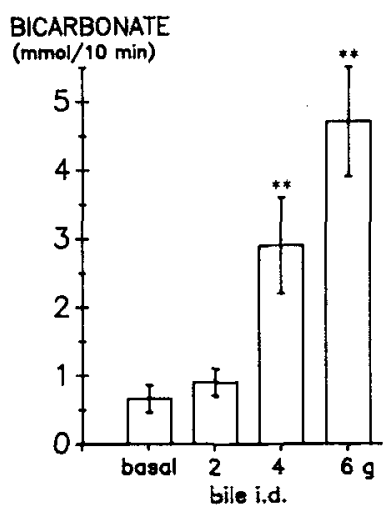

BICARBONATE

(mmol/10 $\mathrm{min}$ )
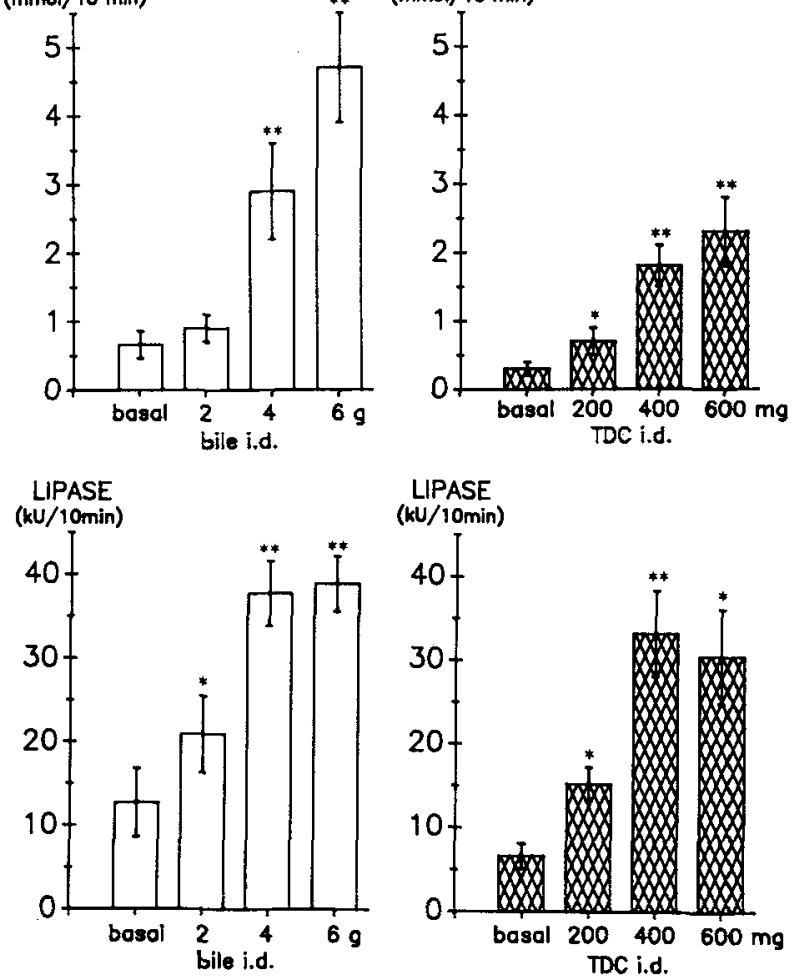

FIG. 5. Dose-response plot of i.d. bile (left) and TDC (right) on pancreatic bicarbonate (top) and lipase (bottom) output $(n=10)$.

crease of peripheral VIP levels by i.d. perfusion with hypertonic glucose solutions in humans and hypertonic saline and glucose solutions in pigs. Thus, a nonspecific effect of bile may be ruled out. In contrast to the results in man, Chayvialle et al. (12) noted no change in systemic and only an insignificant rise in portal plasma VIP concentrations after i.d. application of $3 \mathrm{~g}$ bile in dogs. This discrepancy may be due to species differences and/or the different study design (26). In the latter experi-

TABLE 1. Effect of i.d. bile and TDC on volume and bicarbonate secretion and on lipase, trypsin, and amylase output $(\mathrm{n}=10)^{a}$

\begin{tabular}{|c|c|c|c|c|c|c|c|c|}
\hline & \multicolumn{4}{|c|}{ Bile (g) } & \multicolumn{4}{|c|}{ TDC (mg) } \\
\hline & Basal & 2 & 4 & 6 & Basal & 200 & 400 & 600 \\
\hline $\begin{array}{l}\text { Volume } \\
\text { (ml/10 min) }\end{array}$ & $18.2 \pm 3.5$ & $33.8 \pm 5.5$ & $63.4 \pm 5.3^{* *}$ & $83.2 \pm 6.0^{* *}$ & $10.3 \pm 1.4$ & $32.7 \pm 4.7^{*}$ & $47.2 \pm 6.3^{* *}$ & $61 \pm 9.3^{* *}$ \\
\hline $\begin{array}{l}\text { Bicarbonate } \\
\text { (mmol/10 } \mathrm{min} \text { ) } \\
\text { Lipase }\end{array}$ & $0.6 \pm 0.2$ & $0.9 \pm 0.2$ & $2.9 \pm 0.7^{* *}$ & $4.7 \pm 0.8^{* *}$ & $0.3 \pm 0.1$ & $0.7 \pm 0.2^{*}$ & $1.8 \pm 0.3^{* *}$ & $2.3 \pm 0.5^{* *}$ \\
\hline & $12.7 \pm 4.1$ & $20.9 \pm 4.6^{*}$ & $37.7 \pm 3.9^{* *}$ & $38.9 \pm 3.3^{* *}$ & $6.6 \pm 1.5$ & $15.2 \pm 2.0^{*}$ & $33.2 \pm 5.1^{* *}$ & $30.5 \pm 5.6^{* *}$ \\
\hline $\begin{array}{l}(\mathbf{k U} / 10 \mathrm{~min}) \\
\text { Amylase } \\
(\mathbf{k U} / 10 \mathrm{~min})\end{array}$ & $\begin{array}{l}0.6 \pm 0.2 \\
4.2 \pm 1.5\end{array}$ & $\begin{array}{l}1.2 \pm 0.2 \\
9.1 \pm 2.6\end{array}$ & $\begin{array}{c}2.6 \pm 0.4^{* *} \\
12.2 \pm 2.4^{* *}\end{array}$ & $\begin{array}{r}2.3 \pm 0.2^{* *} \\
12.2 \pm 1.9^{* *}\end{array}$ & $\begin{array}{l}0.2 \pm 0.9 \\
2.8 \pm 0.8\end{array}$ & $\begin{array}{l}1.1 \pm 0.3^{*} \\
5.6 \pm 1.1^{*}\end{array}$ & $\begin{array}{l}2.2 \pm 0.4^{* *} \\
9.9 \pm 2.3^{*}\end{array}$ & $\begin{array}{l}1.9 \pm 0.4^{* *} \\
10.6 \pm 2.5^{*}\end{array}$ \\
\hline
\end{tabular}

${ }^{a}$ A single asterisk indicates $p \leqslant 0.05$ and two asterisks $p \leqslant 0.01$ compared with the basal value. 
ments, pancreatic juice was not withdrawn from the duodenum.

TDC, i.d. applied in a physiological dose range, significantly enhanced plasma VIP levels (Fig. 2). Integrated plasma VIP, however, increased significantly only after $200 \mathrm{mg}$ of TDC and showed no further increase even at the highest dose of TDC used. As VIP was measured in peripheral, not in portal plasma, peaks of VIP release were only small and short lasting. Therefore, intraindividual variations might have contributed to the missing dose dependence.

VIP resembles secretin in its primary structure and its ability to stimulate pancreatic volume and bicarbonate secretion (27). VIP is a secretin-like full agonist in cats $(27,28)$, but only a partial agonist in dogs (29), pigs (30), and man (31). The low potency of VIP [1-5\% as effective as secretin (32)] has been used as an argument against an important physiological role of VIP as a hormonal stimulant of hydrokinetic pancreatic secretion. Because the existence of VIP-containing endocrine cells of the gut is questioned as well (33), a hormonal action of VIP on the exocrine pancreas is uncertain.

VIP is, however, now generally accepted as a peptidergic neurotransmitter $(34,35)$. This regulatory peptide is localized in vagal nerve fiber endings and in a dense network of peptidergic nerves in the pancreas (36-38). Moreover, VIP-ergic nerves travel along pancreatic ducts capable of water and bicarbonate secretion (39). Electrical stimulation of the vagus nerve in the isolated perfused pig pancreas induces an atropine-resistent enhancement of pancreatic volume and bicarbonate secretion and a release of VIP into the portal effluent as well (3941).

As VIP is known to be rapidly degraded (34) and extracted from portal blood by the liver (42), only a small fraction escapes to the peripheral venous blood. Consequently, the increase of VIP in peripheral plasma after i.d. bile or TDC apparently corresponds to higher VIP concentrations in the portal vein. Moreover, at the site of VIP release, i.e., the synaptic cleft between the VIP-ergic nerve terminals and the receptors in the pancreas, sufficiently high concentrations of VIP have to be assumed to be able to stimulate water and bicarbonate secretion (40). Therefore, an increase of VIP measured in peripheral plasma may be an expression of an "overspill" phenomenon of VIP from the synaptic cleft into the venous effluent.

It cannot be excluded, that the bile-induced in- crease of plasma VIP partially originates from VIPergic neurons of the myenteric and submucous plexus of the duodenum or upper jejunum. Such a release, however, seems unlikely because very high amounts of bile $(10.8 \mathrm{~g})$ applied into the ileum of dogs did not influence peripheral plasma VIP levels (43).

Thus, neuronally released VIP may contribute to the mediation of pancreatic volume and bicarbonate secretion induced by i.d. bile or TDC, although VIP is considered merely as a partial agonist of secretin in man.

Ingestion of a meal evokes not only stimulatory but also inhibitory mechanisms (13), probably to prevent an "overstimulation" of the effector organs (e.g., pancreas) $(16,44)$. Previously, we found a dose-dependent increase of plasma PP levels after i.d. application of bile or TDC (1). The present study shows, that somatostatin is also released (Figs. 1-3). There was observed not only a significant increase of plasma SLI concentrations, but also a dose-dependent augmentation of integrated SLI after bile and 200 and $400 \mathrm{mg}$ of TDC. An acidinduced rise of SLI (17) can be excluded (see above). In contrast, Burhol et al. (17) did not find a significant change of plasma SLI after duodenal infusion of $3 \mathrm{~g}$ cattle bile in man. The reason for this discrepancy remains unclear. On the other hand, Chayvialle et al. (12) noted a significant increase of SLI in portal and peripheral plasma after i.d. application of $3 \mathrm{~g}$ bile in dogs. Gel chromatographic analysis of plasma SLI released by bile revealed that total SLI consists of approximately $60 \%$ somatostatin- 28 and $40 \%$ somatostatin-14. The release of somatostatin-28 may primarily be due to a direct action of bile on the duodenal D cells, because somatostatin-28 is predominantly released from the proximal segment of the small intestine $(45,46)$. Somatostatin-14 is believed to originate from the stomach and the pancreas $(45,46)$. Because in our experiments a duodenogastric reflux was only rarely observed, a release of somatostatin-14 caused by a direct action of bile on gastric D cells seems unlikely. As SLI is also released by vagal stimulation $(17,47)$, neural mechanisms may be responsible for the bile-induced release of somatostatin- 14 from the pancreas. In this context, it is noteworthy that cholinergic mechanisms are activated by bile as indicated by bile-induced PP release (1) and by Forell (22). Gastroenteropancreatic peptides (e.g., secretin) are involved in the mediation of the bile effect on the exocrine pancreas (1). Therefore, additional 
release of somatostatin secondary to these peptides (48) warrants discussion.

After the highest dose of bile, the increase of plasma SLI concentrations was comparable to that found postprandially $(15,17)$. Moreover, postprandial plasma levels of SLI are capable of inhibiting exocrine pancreatic secretion (15), especially with respect to the ecbolic output (49). Therefore, the release of somatostatin may-together with that of PP (1)-be responsible for the lack of further increase of enzyme secretion after the highest doses of bile and TDC, respectively.

Acknowledgment: The authors wish to thank Mrs. E. Hotz, Mrs. H. Mitra, and Mrs. K. Sippel for their valuable technical assistance. The study was supported by the Wilhelm Sander-Stiftung (grant no. 84.012.1-3).

\section{REFERENCES}

1. Riepl RL, Lehnert P, Scharl A, et al. Effect of intraduodenal bile and $\mathrm{Na}$-taurodeoxycholate on exocrine pancreatic secretion and on plasma levels of secretin, pancreatic polypeptide, and gastrin in man. Scand J Gastroenterol 1990;25:4553.

2. Lehnert P, Hempen I, Fiedler F, et al. Na-taurodeoxycholate acts as a specific intestinal stimulus of exocrine pancreatic secretion in man. Scand J Gastroenterol 1987;22(suppl. 139):14-9.

3. Osnes M, Hanssen LE, Flaten O, Myren J. Exocrine pancreatic secretion and immunoreactive secretin (IRS) release after intraduodenal instillation of bile in man. Gut 1978;19: $180-4$.

4. Osnes M, Hanssen LE, Lehnert P, et al. Exocrine pancreatic secretion and immunoreactive secretin release after repeated intraduodenal infusions of bile in man. Scand $J$ Gastroenterol 1980;15:1033-9.

5. Bondesen S, Christensen H, Lindorff-Larsen K, Schaffalitzky de Muckadell OB. Plasma secretin in response to pure bile salts and endogenous bile in man. Dig Dis Sci 1985;30: $440-4$.

6. Hanssen LE. Pure synthetic bile salts release immunoreactive secretin in man. Scand J Gastroenterol 1980;15:461-3.

7. Häcki WH. Secretin. Clin Gastroenterol 1980;9:609-32.

8. Singer MV. Pancreatic secretory response to intestinal stimulants: a review. Scand J Gastroenterol 1987;22(suppl. 139): $1-13$.

9. Doyle HR, Lluis F, Rayford PL. Secretin. In: Thompson JC, Greeley GH, Townsend CM, eds. Gastrointestinal endocrinology. New York: McGraw-Hill, 1987:223-33.

10. Lehnert P, Forell MM, Jaeger E, Moroder L, Wünsch E. Hydrokinetic activity of secretin and secretin analogues, modified in the $\mathrm{N}$-terminal sequence, and of vasoactive intestinal peptide in the dog pancreas. Digestion 1981;22:85-8.

11. Burhol PG, Lygren I, Waldum HL, Jorde R. The effect of duodenal infusion of bile on plasma VIP, GIP, and secretin and on duodenal bicarbonate secretion. Scand J Gastroenterol 1980;15:1007-11.

12. Chayvialle J-A, Miyata M, Rayford PL, Thompson JC. Effects of test meal, intragastric nutrients, and intraduodenal bile on plasma concentrations of immunoreactive somatostatin and vasoactive intestinal peptide in dogs. Gastroenterology 1980;79:844-52.
13. Adler G, Beglinger $C$. Hormones as regulators of pancreatic secretion in man. Eur J Clin Invest 1990;20(suppl. 1): S27-\$32.

14. Greenberg GR, Adrian TE, Baron JH, McCloy RF, Chadwick VS, Bloom SR. Inhibition of pancreas and gallbladder by pancreatic polypeptide. Lancet 1978;2:1280-2.

15. Gyr K, Beglinger C, Köhler E, Trautzl U, Keller U, Bloom SR. Circulating somatostatin. J Clin Invest 1987;79:15951660.

16. Layer P, v.d. Ohe M, Müller MK, Beglinger C. Effects of somatostatin on the exocrine pancreas. Scand J Gastroenterol 1991;26:129-36.

17. Burhol PG, Lygren I, Jenssen TG, Florholmen J, Jorde R. Somatostatin release and plasma molecular somatostatin components in man. Acta Physiol Scand 1984;121:223-8.

18. Otte M. Multi-centre study of the EPC for standardization of pancreatic function. Digestion 1985;32:207-8.

19. Riepl RL, Kowalski C, Lehnert P, Hotz E. Der Einfluss von einzeln oder in Kombination verabreichten Gallensalzen im Duodenum auf die exokrine Pankreas sekretion beim Menschen. Klin Wochenschr 1992;69(Suppl. 28):155.

20. Gries E, Hotz J, Goebell H. Pancreatic exocrine secretion in response to intraduodenal infusion of different detergent agents in anesthetized cats. Digestion 1986;34:61-7.

21. Hotz J, Hartmann W, Gries E, Klunk I, Goebell H. Stimulation of pancreatic secretion by intraduodenal bile acids: evidence of independence on intraduodenal pH. Dan Med Bull 1979;26(suppl. 1):69.

22. Forell MM. Bile salts as stimulants of pancreatic secretion. In: Andersson S, ed. Frontiers in gastrointestinal hormone research. Stockholm: Almqvist \& Wiksell, 1973:277-82.

23. Schapiro H, Britt LG, Evans SR, Wilson H. Effect of infusion of hypertonic fluids into the upper intestines on pancreatic secretion. Am J Surg 1967;113:65-9.

24. Teichmann RK, Swierczek JS, Rayford PL, Thompson JC. Effect of duodenal osmolality on gastrin and secretin release and on gastric and pancreatic secretion. World J Surg 1979; 3:623-30.

25. Schaffalitzky de Muckadell OB, Fahrenkrug J, Holst JJ, et al. Release of vasoactive intestinal polypeptide (VIP) by intraduodenal stimuli. Scand J Gastroenterol 1977;12:793-9.

26. Riepl RL, Lehnert $P$. The role of bile in the regulation of exocrine pancreatic secretion. Scand J Gastroenterol 1992; 27:625-31.

27. Said I, Mutt V. Isolation from porcine intestinal wall of a vasoactive octacosapeptide related to secretin and to glucagon. Eur J Biochem 1972;28:199-204.

28. Konturek SJ, Domschke S, Domschke W, Wünsch E, Demling $\mathrm{L}$. Comparison of pancreatic responses to portal and systemic secretin and VIP in cats. Am J Physiol 1977;232: E156-8.

29. Konturek SJ, Thor P, Dembinski A, Krol R. Comparison of secretin and vasoactive intestinal peptide on pancreatic secretion in dogs. Gastroenterology 1975;68:1527-35.

30. Jensen SL, Fahrenkrug J, Holst JJ, Nielsen OV, Schaffalitzky de Muckadell OB. Secretory effects of VIP on isolated perfused porcine pancreas. Am J Physiol 1978;235: E387-E391.

31. Domschke S, Domschke W, Rösch W, et al. Vasoactive intestinal peptide: a secretin-like partial agonist for pancreatic secretion in man. Gastroenterology 1977;73:478-80.

32. Modlin IM, Mitchel SJ, Bloom SR. The systemic release and pharmacokinetics of VIP. In: Bloom SR, ed. Gut hormones. Edinburgh: Churchill Livingstone, 1978;470-4.

33. Larsson LI, Fahrenkrug J, Schaffalitzky de Muckadell O, et al. Localization of vasoactive intestinal peptide (VIP) to central and peripheral neurons. Proc Natl Acad Sci USA 1976; 73:3197-200. 
34. Said SI. Vasoactive intestinal peptide. $J$ Endocrinol Invest 1986;9:191-200.

35. Fahrenkrug J. Vasoactive intestinal peptide. In: Makhlouf GM, ed. Handbook of Physiology Bethesda: Amer Physiol. Soc., 1989;II:611-29.

36. Holst JJ. Neuronal control of pancreatic exocrine secretion. Eur J Clin Invest 1990;20(suppl. 1):S33-S39.

37. Larsson L-I, Fahrenkrug J, Holst JJ, Schaffalitzky de Muckadell $O B$. Innervation of the pancreas by vasoactive intestinal polypeptide (VIP) immunoreactive nerves. Life Sci 1978; 22:773-80.

38. Larsson LI, Rehfeld JF. Peptidergic and adrenergic innervation of pancreatic ganglia. Scand J Gastroenterol 1979;14: 433-7.

39. Holst JJ, Fahrenkrug J, Knuhtsen S, Jensen SL, Poulsen SS, Nielsen OV. Vasoactive intestinal polypeptide (VIP) in the pig pancreas: role of VIPergic nerves in control of fluid and bicarbonate secretion. Regul Pept 1984;8:245-59.

40. Fahrenkrug J, Schaffalitzky de Muckadell OB, Holst JJ, Jensen SL. Vasoactive intestinal polypeptide in vagally mediated pancreatic secretion of fluid and $\mathrm{HCO}_{3}$. Am J Physiol 1979;237:E535-40.

41. Holst JJ, Knuhtsen S, Jensen SL, Fahrenkrug J, Larsson LI, Nielsen OV. Interrelation of nerves and hormones in stomach and pancreas. Scand J Gastroenterol 1983;18(Suppl. 83):85-99.

42. Hunt S, Vaamonde CA, Rattasal T, et al. Circulating levels of vasoactive intestinal polypeptide in liver disease. Arch Int Med 1979;139:994-8.
43. Chijiiwa Y, Misawa T, Ibayashi H. Evidence of local mechanism involvement in vasoactive intestinal polypeptide release from canine small intestine. Gastroenterology 1986;90: 1877-81.

44. Schusdziarra V. Physiological significance of gastrointestinal somatostatin. Horm Res 1988;29:75-8.

45. Baldissera FGA, Nielsen OV, Holst JJ. The intestinal mucosa preferentially releases somatostatin-28 in pigs. Regul Pept 1985;11:251-62.

46. Ensick JW, Laschansky EC, Vogel RE, Simonowitz DA, Roos BA, Francis BH. Circulating prosomatostatin-derived peptides. J Clin Invest 1989;83:1580-9.

47. Vinik AI, Levitt NS, Pimstone BL, Wagner L. Peripheral plasma somatostatin-like immunoreactive responses to insulin hypoglycemia and a mixed meal in healthy subjects and in noninsulin-dependent maturity-onset diabetics. J Clin Endocrinol Metab 1981;52:330-7.

48. Newman JB, Lluis F, Townsend CM. Somatostatin. In: Thompson JC, Greeley GH, Townsend CM, eds. Gastrointestinal endocrinology. New York: McGraw-Hill, 1987;286299.

49. Gullo L, Priori P, Scarpignato C, Baldoni F, Mattioli G, Barbara L. Effect of somatostatin 14 on pure human pancreatic secretion. Dig Dis Sci 1987;32:1065-70.

50. Fiedler F, Riepl RL, Teufel J, Lehnert P. The effect of intraduodenal bile and Na-taurodeoxycholate on plasma concentrations of somatostatin and VIP in man. Eur J Clin Invest 1991;21(II):14. 